\title{
A Development of Questionnaire for Assessing Implementation of Multicultural Education in Learning at Elementary School
}

\author{
Lalu Hamdian Affandi \\ Mataram University, Indonesia \\ Jl. Majapahit No.62 Mataram, West Nusa Tenggara. E-mail: hamdianfkip@gmail.com
}

\begin{abstract}
The aim of this research is to develop a questionnaire of multicultural education implementation in learning at elementary schools. As a preliminary study, this research target is to identify a factor(s) underlying questionnaire items. Questionnaire was developed based on four of five dimension of multicultural education proposed by James Banks in four point Likert Scale. Data were collected from 150 elementary school teachers employed in Lombok, West Nusa Tenggara. In order to achieve above goal, exploratory factor analysis was conducted through maximum likelihood method with promax extraction procedure. Eigenvalues greater than 1 and scree test were used to retain a factor(s) underlying items construct. Whereas Cronbach's alpha is used to determine questionnaires reliability. This research found that from 54 items, there are 29 items valid for 6 factors of multicultural education dimensions with item load 0.40 or larger and 0.878 Cronbach's alpha.
\end{abstract}

Key Words: assessment of multicultural education implementation, elementary school

\begin{abstract}
Abstrak: Tujuan dari penelitian ini adalah untuk mengembangkan kuesioner implementasi pendidikan multikultural dalam pembelajaran di sekolah dasar. Sebagai studi pendahuluan, sasaran penelitian ini adalah untuk mengidentifikasi faktor-faktor yang mendasari butir kuesioner. Kuesioner dikembangkan berdasarkan empat dari lima dimensi pendidikan multikultural yang diajukan oleh James Banks dalam empat titik Skala Likert. Data dikumpulkan dari 150 guru sekolah dasar di Lombok, Nusa Tenggara Barat. Untuk mencapai tujuan di atas, analisis faktor eksploratori dilakukan melalui metode maximum likelihood dengan prosedur ekstraksi promax. Eigenvalues lebih besar dari 1 dan scree test digunakan untuk mempertahankan butir yang mendasari item construct. Sedangkan alpha Cronbach digunakan untuk menentukan reliabilitas kuesioner. Penelitian ini menemukan bahwa dari 54 item, ada 29 item yang valid untuk 6 faktor dimensi pendidikan multikultural dengan item load 0,40 atau lebih besar dan 0,878 alpha Cronbach.
\end{abstract}

Kata kunci: penilaian pelaksanaan pendidikan multikultural, sekolah dasar

Indonesia is a country with more than 300 ethnics spreads in more than 1300 islands. Diversity in Indonesian population also can be seen in fact that there are more than 6 religions held by Indonesian people. Those facts tell us that Indonesia is a multicultural society with various ethnicity, religion, and language. A history of Indonesian peoples also tells us that multicultural society within Indonesia had a different characteristic from other countries. If in other country a stranger came as an immigrant, this fact is rarely found in Indonesia. But what is obviously same between Indonesia and other countries like United States or United Kingdom are their populations were found to have a various cultural background.
In Indonesian case cultural diversities were also determined by an amount of migration movement from one province to another. At least 1 to 2 people in each province of Indonesia have a different cultural background (Badan Pusat Statistik, 2015). This fact also found in elementary school classroom, where several students came from different ethnicity from majority of their classmate. At the same time, Indonesian legislation No. 20 Year 2003 point out that education is carried out by democratic and just ways and without discrimination. This principle prosecute teachers and schools to make sure that all students have an equal opportunity to learn and to success in both, academically and socially, regardless of their cultural background. 
This principle also found in the consensus about the characteristic of effective school, that is to assure that all of the children in the school have an equal right to success regardless of their background (Townsend, 2003).

Success for all students academically means that all students have an equal opportunity to strive for and achieve an optimum level of their potentials which measured by their learning result. This exhortation must be responded by teachers and schools by providing for all students a learning condition suitable to their cultural background. And at the same time, teachers need to find a way to teach with cultural sensitivity. In every lesson plan, there will be a cultural bias from teachers if he or she doesn't aware about how their cultural values and norms affected the lesson he or she planned (Gay, 2002). And success of students socially means that all of students are accepted as they are, with their diverse cultural value and norms.

This condition allows students to express their unique ways of thinking and behaving. Only by accepted them as they are, student will feel comfort when they came into school and classroom. On such condition, students can fully focus their attention to mastery a lesson presented without distracting their attention to any cultural or social threat from other students (Gay, 1994). Providing for students a comfortable and safety condition to learn are prerequisites condition to raise students potential up to their optimum levels. In doing so, we need to make sure that school and classrooms are safe and comfortable places for all students. In other words, to pursue the goal of education for all we need to implement multicultural education so our students can learn anything they supposed to learn.

Multicultural education has a different meaning for different scholar. For some scholars, multicultural education is an educational effort to reform the school and other educational institutions so that students from diverse racial, ethnic, and social-class groups will experience educational equality (Banks, 1993A). As a reforming force, multicultural education strives to change educational condition, structurally and culturally. A more comprehensive definition proposed by Gay (1994), with her statement that multicultural education is a philosophy, a methodology for educational reform, and a set of a specific content areas within instructional programs. Multicultural education means learning about, preparing for, and celebrating cultural diversity. This definition requires more change in school and classroom practices.
According to definitions above, the main goals of multicultural education are ethnic and cultural literacy, personal development, attitude and values clarification, multicultural social competence, basic skill proficiency, educational equity and excellence, and empowerment for societal reform (Gay, 1994). In short, we can classify goals of multicultural education as success of student academic achievement, optimum personal and social development, and student readiness for empowering their society. Student success in school is measured by their basic skill proficiency and other standard they must master. Optimum personal and social development is a state of students being when they can develop their potential to optimum level. As a social creature, multicultural education also strive for making students have a skill to be socially competent and to build a close and productive social relationship with others from diverse cultural background. Despite personal and academic development, multicultural educations goal also included preparing students for participating in an effort to make social environment become a better place for diverse social and cultural persons.

In order to pursue those goals, there must be a systematic change in ways school managed and learning within classrooms carried out. At school level, multicultural education needs to being implemented by providing safety environment for student to interact each other in a respectful ways. This condition allows student to focus more attention for learning than to protect themselves from unconscious attack stems from unsafe school environment. At classroom level, teachers need to change the way they teach by treating student equally and consider student cultural background as a basis for planning and running their learning process.

Condition explained above delineates a need for implementing multi-cultural education at both level, schools and classrooms levels. Implementing multicultural education needs a systematic approach so that implementation can be measured accurately on its process and effect. Unfortunately, there are a few literatures published in scientific references can be used as a guidance at implementing multicultural education. Almost all of literature which was published is weakly shows relationship between theories and practices (Sleeter and Grant, 1987). Another review of multicultural education research shows that research had carried out can be divided into a few genre which was rarely touch the area of instruments development can 
be used to assess multicultural education implementation, particularly regarding to learning process within classroom level (Bennet, 2001). In other words, we still need for an instrument to measure how well multicultural education implemented.

\section{Questionnaire Development}

The goal of this research is to develop and validate an instrument can be used to assess whether multicultural education had implemented or not. The instrument was developed based on James Banks (1993A; 2010) theory about the dimensions of multicultural education; those are content integration, knowledge construction, equity pedagogy, prejudice reduction, and empowering school culture. This research only use 4 from 5 dimensions above because the last dimension can't directly implemented within learning in a classroom. Content integration is the using of examples, data, and information from students diverse cultural background to describe learning material. This dimension can apply to activate student prior knowledge, improving student motivation and self-concept, and to build intercultural understanding among students. Knowledge construction is about how teachers help students to understand, questioning, and even to create their own interpretation about the past and the present knowledge development (Banks, 1993B). Teachers can use learning strategies which can gives a student a wide range of freedom to create and construct their own knowledge and interpretation to the information presented for them. The main point of this dimension depends heavily on how teachers give a student an opportunity to investigate and determine how cultural assumption, frames of reference, perspectives, and biases within a discipline influence the ways knowledge is constructed. Because of that, Banks propose for teachers to use a transformative learning approach which is not only aimed at mastering information but also to give student a chance to examine it in real world situation.

Equity pedagogy is teaching strategies and classroom environments that help students from diverse racial, ethnic, and cultural to attain the knowledge, skills, and attitudes they need to function effectively within, and help create and perpetuate, a just, humane, and democratic society (Banks and Banks, 1995). This means that student must create a just learning environment using compatible learning strategies. As we all know that every student had a different thinking style, different ways of behaving and perceiving, so teachers need to go beyond their own cultural biases by collect- ing information about students' diverse cultural background. To help students function effectively, teachers must combine equity pedagogy with content integration. This suggestion is proposed to ensure that student can evaluate or examine the information they accept through their own ways of thinking. So that situation can flourish student sensitivity to unequal condition existed in society they live in.

Prejudice reduction become more important in a situation where every person can make a social contact with other from diverse cultural background. Prejudice is naive conclusion made by a person based in their personal experiences (Banks, 2010). In classroom or school setting, prejudice can be held by students or even teachers. They usually had speculative views about others from diverse cultural background. Social interaction is in dangerous situation if each party held wrong impression about other because they tend to believe their unconscious prejudice. At diminishing such prejudice, teachers must be at front to create a condition within which student can interact each other to clarify their own views about other. This effort called prejudice reduction.

\section{METHOD}

This research is a preliminary study aimed at identifying a factor(s) underlying the questionnaire has been developed. Questionnaire distributed to teacher by came to school where teachers taught. From 157 questionnaires had been distributed, only 150 were sent back by teachers. Data from those questionnaires were analyzed using exploratory factor analysis technique. It is assumed that exploratory factor analysis is an appropriate technique because it is usually used by a researcher as tools to develop and refine a new questionnaire. Exploratory factor analysis can conducted through many methods of extraction and rotation techniques. In this research, common factor method use as an extraction through minimum likelihood because of it advantage in separates unique variation from common variation in determining communalities among items questionnaire (Fabrigar, Wegener, Mac Callum, and Strahan, 1999; Ford, MacCallum, and Tait, 1986). Whereas in rotating technique, researchers use oblique rotation because this technique will better represent reality and produce better simple structure. There are many choices available in an oblique rotation procedure; those are direct oblimin, promax, equamax, and quartimax. In this research, direct oblimin is a best choice to be choose because of this rotation pro- 
cedure can produce ideally high loadings on uniform factor and there for result in simple interpretable solution (Fabrigar, Wegener, MacCallum, and Strahan, 1999; Conway and Huffcutt, 2003). The last decision to be made in exploratory factor analysis is factor to be retained. At make such decision, researcher uses some rules, those are eigenvalues greater than 1 and scree test, items loading 0.40 or above for each factor (Ford, MacCallum, and Tait, 1986), cross loading less than 0.50 should be dropped out, and a factor with fewer than three items should be dropped out because such factor is generally weak and unstable (Osborne and Costello, 2009).

Data were gained from 150 teachers of elementary schools employed in Lombok, West Nusa Tenggara, chosen by simple random sampling technique. There are several demographical characteristics of sample, including grade level (49\% teacher in upper grade and $51 \%$ in lower grade), gender (27.8\% male and $72.2 \%$ female), employment status ( $71.5 \%$ PNS), and ethnicity (75.5\% sasak).

\section{RESULTS}

All of data analyzing process conducted using SPSS 16 for windows, using maximum likelihood extraction method and followed by promax rotation procedure. Criteria for factor(s) retaining are items load must 0.4 or larger, eigenvalues greater than 1 , and minimum items for factors retaining are 4 . Overall finding shows that from 54 items constructed, there are 29 items valid for 6 factors with 0.878 Cranach Alpha. These factors are critical thinking practices for student consist of 9 items; opportunity for student to reduce prejudice consist of 4 items; cultural diversity as a learning resource consist of 4 items, equality in learning opportunity consist of 4 items; teacher's knowledge about students' cultural background consist of 4 items; and encouragement for students learning initiatives consist 4 items.

\section{DISCUSSION}

Implementation of multicultural education cannot be seen solely as curriculum reforms by injecting cultures component into learning material. Rather, multicultural education need to implemented comprehensively through diversifying curriculum by treating cultural diversity as a learning resources, more equal treatment for student regardless of their cultural background, and implementing appropriate learning strat- egies based on student diversity. Such as reform movement calls for a different kind of learning process facilitated by teacher. Finding of this research shows a fundamental change in educational practice, particularly about how learning designed and carried out.

A fundamental change as a sign of implementation of multicultural education can be distinguished into 6 factors, these are critical thinking practices for student; opportunity for student to reduces prejudice; cultural diversity as a learning resource, equality in learning opportunity; teacher's knowledge about students' cultural background; and encouragement for students learning initiatives. Critical thinking practices refer to the degree of stimulation presented by teacher for student to evaluate, use, and apply information they attain in learning activities. In the same manner, critical thinking practices relate to an opportunities provided by teacher to give student a chance to construct their own knowledge. Based on James Banks (2010) dimension of multicultural education, this factor is similar to knowledge construction. Banks point out that knowledge construction is a process by which teacher help student to identify how culture influences the construction of knowledge and it's meaning for each person. In more detail, critical thinking practices refers to several classroom behavior such as gives student a chance to asks and answers question, so he or she can understood the way he or she think.

Each student comes to school not with empty experiences. Rather, they came to school with knowledge they attain from their daily life. Using this kind of perspective, teacher can gives students an opportunity to examine knowledge taught in classroom in accordance with their prior knowledge. Through this way of learning, student can determines the effect of their cultural experiences in the construction of knowledge. By providing student a chances to think critically, teachers encourage students to make a suitable match between knowledge they already have and new knowledge taught in school.

The ultimate goal of multicultural education was to reform educational enterprises-within classroom and within school as a whole. By this, we strive to make students have a skill to be socially competent and to build a close and productive social relationship with others from diverse cultural background healthy relationship among all of citizen (Gay, 1994). Learning schools setting is expected as an apprenticeship process where student nourish their ability to interact each other without hindered by cultural differences. The most salient cultural barrier in human interaction is prejudice; a naïve conclusion about an attribute or 
characteristics of anybody based on their cultural group membership. To erase prejudice, teachers need to give a student a chance to build a warm, safe, and open dyadic dialog with their classmate. Implementation of multicultural education must create an opportunity for student to reduce prejudice by providing multisource knowledge, encourage student to work collaboratively, or to compare information from one resource to other, and gives student an opportunity to explain or clarify naïve assumption about their self and their cultural life.

Opportunity for student to reduce prejudice is in similar motion with what Banks (2010) notes as prejudice reduction. Prejudice reduction is situation created by teacher to promote a clearer conception from student for other student cultural group. Research conducted in schools with a population of multiracial student shows that interracial interaction is rarely happen (Borman, Timm, al-Amin, and Winston, 2005). Due to this situation, implementation of multicultural education should be a step forward to promote an effort to build a healthier interracial relationship.

The first dimension of multicultural education proposed by Banks (1993) is content integration that is using of examples, data, and information from student's diverse cultural background to describe learning material. By this effort, students learn their cultural heritage, norm, and value, while at the same time they also learn about other cultures. To implement content integration, at least teachers need to treat cultural diversity as a learning resource and have a sufficient knowledge about students' cultural background. To use an example from student cultural background, teacher can give a student a chance for collecting information from their own cultural resources such as their parent, their cultural unique artifact, or other information sources bounded with student cultural background. One of the most striking factors affected student (dis)engagement in classroom setting is that they see a learning material as an at odds with their daily life (Nieto, 2010). At the same time, student engagement can predicts student academic achievement. On the other side, the using of student cultural heritage as a subject to be learned can enhance student selfesteem because they can see their culture as a valuable resource of learning.

At the same time, to implement content integration, teachers need sufficient information about students' cultural background. Such information can attain when teachers have a time to look at student daily life at home. This effort can be done through observation or interview with parent and other community mem-bers where student live (Erickson, 2010). This process named by Lee (2007) as looking for cultural data set that is a process used by teacher to collect information about student and their bio environment outside schools. By "watching" what student do and how com-munity treat them, teacher and school can enhances their understanding about student and gives them a broad useful information to integrate with learning ma-terial to be thought in classroom. Activities conducted by teacher and school to gain cultural data set can yield teacher's knowledge about students' cultural background.

The next component found as an underlying factors of implementation of multicultural education is equality in learning opportunity; creating a democratic, safe, and supportive learning environment within which student has an obligation listen to and appreciate others voices. This factor is exemplar to equity pedagogy in James Banks conception about multicultural education dimension. Teacher can create an equal opportunity for student to learn by ensuring equality in right and obligation at learning activities and creating a learning environment that is supportive for students to collaborate. In his explanation about equity pedagogy, Banks and Banks (1995) point out that this dimension is associate with teaching strategies and classroom environments that help students from diverse racial, ethnic, and cultural attain the knowledge, skills, and attitudes they need to function effectively within, and help create and perpetuate, a just, humane, and democratic society.

The last factor underlying implementation of multicultural education based on this research is an encouragement for students learning initiatives; the teachers behavior that create and maintain student initial engagement in learning activities through implementation of learning strategy and arranging classroom physical setting that encourage student to try their ideas out and feel pride about their idea. Similar to previous factor, this factor tightly related to Banks conception about equity pedagogy. If equity pedagogy is using learning strategies and creating environment that safe for student to learn according to their learning style, this factor emphasis on build and maintain initiative and pride of student creation.

One thing to bear in mind is these 6 factors are interrelated and can't be separated. Only implementing critical thinking and ignoring cultural diversity as resource of learning would simply create an unjust cultural representation within curriculum. At the same time, only use cultural diversity as resource of learning with- 
out compound it with a greater opportunity for student to practice critical thinking would not prepared student with sufficient capability for evaluating information, and then this situation can lead student to keep their prejudice to other.

\section{CONCLUSIONS}

The factors been found from this research have a suitable match to dimension of multicultural education proposed by James Banks. These factors consist of critical thinking practices for student, opportunity for student to reduce prejudice; cultural diversity as a learning resource, equality in learning opportunity; teacher's knowledge about students' cultural background; and encouragement for students learning initiatives. These six factors were interrelated and supported one another.

A suggestion stems from this research is multicultural education need a careful learning design to integrate learning activities with student cultural background. Because this research is based only on four from five dimension of multicultural education, there is a need to undertake another research aimed at assessing implementation of multicultural education in a more comprehensive way not only including dimension of multicultural education directly related to classroom learning activities, but also include an effort to empower school culture. Furthermore, this research suggest for further examination to assess the validity of factors have been found by engaging larger sample size.

\section{REFERENCES}

Badan Pusat Statistik. (2015). Penduduk Indonesia: Hasil Survey Penduduk Antar Sensus 2015. Jakarta; Badan Pusat Statistik.

Banks, C.A.M., and Banks, J.A. (1995). Equity Pedagogy: an Essential Component of Multicultural Education. Theory into Practice, 34(3), 152-158.

Banks, J.A. (1993A). Multicultural Education: Historical Development, Dimension, and Practice. Review of Research in Education, 19, 3-49.

Banks, J.A. (1993B). The Canon Debate, Knowledge Construction, and Multicultural Education. Educational Researcher, 22(5), 4-14.

Banks, J.A. (2010). Multicultural Education: Characteristics and Goals. In James A. Banks and Cherry A. McGee Banks (eds). Multicultural Education: Is- sues and Perspectives, 7th Edition. New Jersey; John Wiley \& Sons, 3-30.

Bennet, C. (2001). Genres of Research in Multicultural Education. Review of Educational Research, 71(2), 171-217.

Borman, K.M., Timm, P., al-Amin, Z., \& Winston, M. (Eds.). (2005). Research and Multicultural Education: From Margins to the Mainstream: Using Multiple Strategies to Assess Multicultural Education in a School District. London; The Falmer Press; 6885.

Conway, J.M., and Huffcutt, A.I. (2003). A Review and Evaluation of Exploratory Factor Analysis Practices I Organizational Research. Organizational Research Methods, 6(2), 147-168.

Erickson, F. (Ed.). (2010). Multicultural Education: Issues and Perspectives, 7th Edition: Culture in Society and in Educational Practices. New Jersey; John Wiley \& Sons, Inc: 33-56.

Fabrigar, L.R., Wegener, D.T., MacCallum, R.C., and Strahan, E.J. (1999). Evaluating the Use of Exploratory Factor Analysis in Psychological Research. Psychological Methods, 4(3), 272-299.

Ford, J.K., MacCallum, R.C., and Tait, M. (1986). The Application of Exploratory Factor Analysis in Applied Psychology: a Critical Review and Analysis. Personnel Psychology, 39, 291-314.

Gay, G. (1994). A Synthesis of Scholarship in Multicultural Education. NCREL's Urban Education Program as part of its Urban Education Monograph Series. Retrieved from http://www. ncrel.org/sdrs/areas/ issues/educatrs/leadrshp/le0gay.htm.

Gay, G. (2002). Culturally Responsive Teaching in Special Education for Ethnically Diverse Student: Setting the Stage. Qualitative Studies in Education, 15(6), 613-629.

Lee, C.D. (2007). Culture, Literacy, and Learning: Blooming in The Midst of Whirlwind. New York: Teachers College Press.

Nieto, S. (2010). Language, Culture, and Teaching: Critical Perspectives for a New Century 2nd Edition. New York: Routledge.

Osborne, J.W., and Costello, A.B. (2009). Best Practices in Exploratory Factor Analysis: Four Recommendation for Getting the Most from Your Analysis. PanPacific Management Review, 12(2), 131-146.

Sleeter, C.E., and Grant, C.A. (1987). An analysis of multicultural education in the United States. Harvard Educational Review, 57(4), 421-445.

Townsend, T. (2003). Effective Schooling for The Community: Core-plus Education. London and New York: Routledge. 